\title{
Cell-adhesion Inhibitors Produced by a Sea Hare-derived Periconia sp.
}

\author{
III Absolute Stereostructures of Peribysin J and Macrosphelide M
}

\author{
Takeshi Yamada, Katsuhiko Minoura, Reiko Tanaka, Atsushi Numata
}

Received: April 6, 2007 / Accepted: May 29, 2007

(C) Japan Antibiotics Research Association

\begin{abstract}
Peribysin $\mathrm{J}$ and macrosphelide $\mathrm{M}$ have been isolated from a strain of Periconia byssoides originally isolated from the sea hare Aplysia kurodai. Their absolute stereostructures have been elucidated on the basis of spectroscopic analyses using 1D and 2D NMR techniques and some chemical transformations including the modified Mosher's method. These fungal metabolites inhibited the adhesion of human-leukemia HL-60 cells to humanumbilical-vein endothelial cells (HUVEC).
\end{abstract}

Keywords fungus, cell-adhesion inhibitor, peribysin, macrosphelide, Periconia sp.

\section{Introduction}

Based on the fact that some of the bioactive materials isolated from marine animals have been produced by bacteria, we have turned our attention to new antitumour materials from microorganisms inhabiting the marine environment [1 3]. As part of this study, we have previously isolated the cell-adhesion inhibitors, macrosphelides $\mathrm{E} \sim \mathrm{I}, \mathrm{L}[4,5]$ and peribysins $\mathrm{A} \sim \mathrm{I}[6 \sim 8]$, from a strain of Periconia byssoides OUPS-N133 originally isolated from the sea hare Aplysia kurodai. All of these compounds, except for macrosphelide I, inhibited the adhesion of human-leukemia HL-60 cells to human-umbilical-vein endothelial cells (HUVEC) more potently than herbimycin A $[9,10]$. Further investigation of the metabolites from this

T. Yamada (Corresponding author), K. Minoura, R. Tanaka, A. Numata: Osaka University of Pharmaceutical Sciences, 4-20-1, Nasahara, Takatsuki, Osaka 569-1094, Japan,

E-mail: yamada@gly.oups.ac.jp fungal strain has now led to the isolation of new antiadhesion compounds designated peribysin J (1) and macrosphelide M (2) (Fig. 1). We describe herein the absolute stereostructures of $\mathbf{1}$ and $\mathbf{2}$ (Fig. 1) in addition to their inhibition of cell adhesion.

\section{Results and Discussion}

The fungal strain was cultured at $27^{\circ} \mathrm{C}$ for 4 weeks in a medium containing malt extract $1.0 \%$, glucose $1.0 \%$ and peptone $0.05 \%$ in artificial seawater adjusted to $\mathrm{pH} 7.5$, as reported previously [4 8]. The AcOEt extract of the culture filtrate was purified by chromatography on Sephadex LH-20 and silica gel by reversed phase HPLC to afford $\mathbf{1}$ and $\mathbf{2}$. The physico-chemical properties of these compounds are summarized in Table 1.

1 had the molecular formula $\mathrm{C}_{15} \mathrm{H}_{26} \mathrm{O}_{5}$ established by the $[\mathrm{M}]^{+}$peak of $\mathbf{1}$ in high-resolution electron-impact mass spectrometry (HREI-MS). Its IR spectrum exhibited bands at 3384 and $1653 \mathrm{~cm}^{-1}$, characteristic of an alcohol and a double bond. A close inspection of the ${ }^{1} \mathrm{H}$ - and ${ }^{13} \mathrm{C}-\mathrm{NMR}$
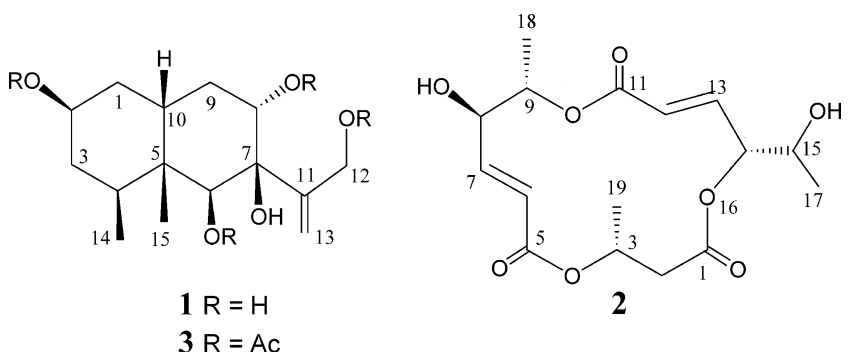

2

Fig. 1 Structures of peribysin $\mathrm{J}(\mathbf{1})$ and macrosphelide $\mathrm{M}$ (2). 
Table 1 Physico-chemical properties of peribysin J (1) and macrosphelide M (2)

\begin{tabular}{|c|c|c|}
\hline & 1 & 2 \\
\hline Appearance & Pale yellow oil & Pale yellow oil \\
\hline$[\alpha]_{D}^{22}$ & -190.1 (с $0.28, \mathrm{EtOH})$ & +5.5 (c $0.30, \mathrm{EtOH})$ \\
\hline \multicolumn{3}{|l|}{ HREI-MS } \\
\hline Found: & $286.1775(\mathrm{M})^{+}$ & $343.1395(\mathrm{M}+\mathrm{H})^{+}$ \\
\hline Calcd: & $286.1773\left(\right.$ for $\mathrm{C}_{15} \mathrm{H}_{26} \mathrm{O}_{5}$ ) & 343.1392 (for $\mathrm{C}_{16} \mathrm{H}_{23} \mathrm{O}_{8}$ ) \\
\hline Molecular formula & $\mathrm{C}_{15} \mathrm{H}_{26} \mathrm{O}_{5}$ & $\mathrm{C}_{16} \mathrm{H}_{22} \mathrm{O}_{8}$ \\
\hline$U V \lambda_{\max }^{\mathrm{EtOH}} \mathrm{nm}(\log \varepsilon)$ & 208 (3.38) & $212(4.09)$ \\
\hline IR $v_{\max }$ (neat) $\mathrm{cm}^{-1}$ & 3384,1653 & $3450,1722,1717,1658,1652$ \\
\hline $\operatorname{TLC~Rf}^{\mathrm{a}}$ & 0.12 & 0.48 \\
\hline \multicolumn{3}{|l|}{ Solubility } \\
\hline soluble & DMSO, $\mathrm{MeOH}, \mathrm{Me}_{2} \mathrm{CO}$ & DMSO, $\mathrm{MeOH}, \mathrm{Me}_{2} \mathrm{CO}$ \\
\hline insoluble & $\mathrm{CH}_{2} \mathrm{Cl}_{2}, \mathrm{H}_{2} \mathrm{O}$ & $\mathrm{H}_{2} \mathrm{O}$ \\
\hline
\end{tabular}

a Silica gel $\left(10 \% \mathrm{MeOH}\right.$ in $\left.\mathrm{CH}_{2} \mathrm{Cl}_{2}\right)$.

Table 2 NMR spectral data of peribysin J (1) in $\mathrm{MeOH}-d_{4}$

\begin{tabular}{|c|c|c|c|c|c|c|}
\hline Position & $\delta_{\mathrm{H}}{ }^{\mathrm{a}}$ & $J / H z$ & ${ }^{1} \mathrm{H}-{ }^{1} \mathrm{H}$ COSY & NOE & $\delta_{\mathrm{C}}$ & $\operatorname{HMBC}(C)^{b}$ \\
\hline $1 \alpha$ & $1.68 \mathrm{dt}$ & $12.4(1 \beta), 4.8(2,10)$ & $1 \beta, 2,10$ & $1 \beta, 2,10$ & $37.38(t)$ & 2,5 \\
\hline$\beta$ & $1.58 \mathrm{td}$ & $12.4(1 \alpha, 2), 4.8(10)$ & $1 \beta, 2,10$ & $1 \alpha, 10,15$ & & 2 \\
\hline 2 & 3.74 tdd & $12.4(1 \beta, 3 \beta), 4.8(1 \alpha), 2.7(3 \alpha)$ & $1 \alpha, 1 \beta, 3 \alpha, 3 \beta$ & $1 \alpha, 3 \alpha, 4,9 \alpha$ & $67.19(d)$ & \\
\hline $3 \alpha$ & $1.60 \mathrm{ddd}$ & $12.4(3 \beta), 3.9(4), 2.7(2)$ & $2,3 \beta$ & $2,4,3 \beta, 14$ & $40.97(t)$ & 2 \\
\hline$\beta$ & $1.22 \mathrm{td}$ & $12.4(2,3 \alpha), 11.0(4)$ & $2,3 \alpha, 4$ & $3 \alpha, 14,15$ & & $2,4,5,14$ \\
\hline 4 & $2.07 \mathrm{dqd}$ & $11.0(3 \beta), 6.8(14), 3.9(3 \alpha)$ & $3 \beta, 14$ & $2,3 \alpha, 6,9 \alpha, 14$ & $33.24(d)$ & $3,14,15$ \\
\hline 5 & & & & & 42.25 (s) & \\
\hline 6 & $3.80 \mathrm{~s}$ & & & $4,12 \mathrm{~A}, 12 \mathrm{~B}, 13 \mathrm{~B}, 14$ & $77.27(d)$ & $4,8,10,15$ \\
\hline 7 & & & & & 80.42 (s) & \\
\hline 8 & $3.87 \mathrm{dd}$ & $10.9(9 \alpha), 5.4(9 \beta)$ & $9 \alpha, 9 \beta$ & $9 \beta, 10$ & $75.81(d)$ & 7,11 \\
\hline $9 \alpha$ & $2.01 \mathrm{td}$ & $12.8(9 \beta, 10), 10.9(8)$ & $8,9 \beta, 10$ & $2,4,9 \beta, 13 \mathrm{~B}$ & $35.42(t)$ & 8,10 \\
\hline$\beta$ & $1.71 \mathrm{ddd}$ & $12.8(9 \alpha), 5.4(8), 4.8(10)$ & $8,9 \alpha, 10$ & $8,9 \alpha, 10$ & & 1,7 \\
\hline 10 & $1.58 \mathrm{dq}$ & $12.8(9 a), 4.8(1 \alpha, 1 \beta, 9 \beta)$ & $1 \alpha, 1 \beta, 9 \alpha, 9 \beta$ & $1 \alpha, 1 \beta, 8,9 \beta, 15$ & 38.77 (d) & \\
\hline 11 & & & & & 150.30 (s) & \\
\hline $12 \mathrm{~A}$ & $4.19 d$ & $13.6(12 B)$ & $12 \mathrm{~B}$ & $6,12 B, 13 \mathrm{~A}$ & $64.46(\mathrm{t})$ & 11,13 \\
\hline B & $4.32 \mathrm{~d}$ & $13.6(12 A)$ & $12 \mathrm{~A}$ & $6,12 \mathrm{~A}, 13 \mathrm{~A}$ & & 11,13 \\
\hline $13 \mathrm{~A}$ & $5.46 \mathrm{~s}$ & & & $12 \mathrm{~A}, 12 \mathrm{~B}, 13 \mathrm{~B}$ & $117.19(t)$ & 7,12 \\
\hline B & $5.66 \mathrm{~s}$ & & & $9 \alpha, 6,13 \mathrm{~A}$ & & 7,12 \\
\hline 14 & $0.85 d$ & $6.8(4)$ & 4 & $3 \alpha, 3 \beta, 4,6,15$ & $17.51(q)$ & $3,4,5$ \\
\hline 15 & $1.00 \mathrm{~s}$ & & & $1 \alpha, 3 \beta, 10,14$ & $17.51(q)$ & $4,5,6,10$ \\
\hline
\end{tabular}

${ }^{a}{ }^{1} \mathrm{H}$ chemical shift values $\left(\delta \mathrm{ppm}\right.$ from $\mathrm{SiMe}_{4}$ ) followed by multiplicity and then the coupling constants $(\mathrm{J} / \mathrm{Hz})$. Figures in parentheses indicate the proton coupling with that position. ${ }^{b}$ Long range ${ }^{1} \mathrm{H}-{ }^{13} \mathrm{C}$ correlations from $\mathrm{H}$ to $\mathrm{C}$ observed in the $\mathrm{HMBC}$ experiment.

spectra of 1 (Table 2) by DEPT and HMQC experiments revealed the presence of one vinylidene (C-11 and $\mathrm{C}-13)$, one secondary methyl (C-14), one tertiary methyl (C-15), four $s p^{3}$-hybridized methylenes (C-1, C-3, C-9 and C-12) including one oxymethylene (C-12), five $s p^{3}$-methines (C-2,
C-4, C-6, C-8 and C-10) including three oxymethines (C-2, $\mathrm{C}-6$ and $\mathrm{C}-8)$, two quarternary $s p^{3}$-carbons (C-5 and C-7) including one oxygen-bearing carbon $(\mathrm{C}-7)$. The ${ }^{1} \mathrm{H}-{ }^{1} \mathrm{H}$ COSY analysis of $\mathbf{1}$ led to a partial structural unit as shown by bold-faced lines in Fig. 2, and supported by HMBC 


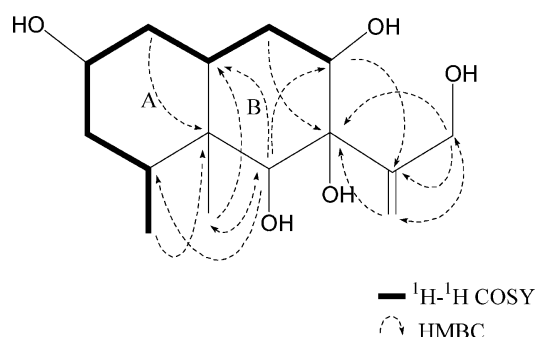

Fig. 2 Selected ${ }^{1} \mathrm{H}^{1} \mathrm{H}$ COSY and $\mathrm{HMBC}$ correlations in peribysin $\mathrm{J}(\mathbf{1})$.

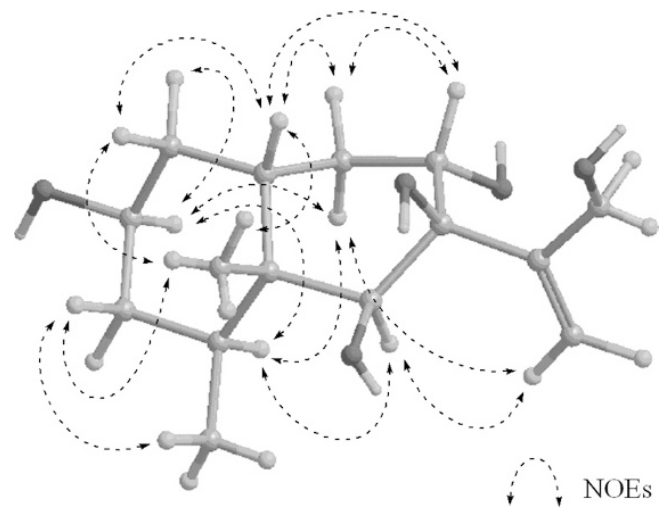

Fig. 3 Observed NOEs for peribysin J (1).

correlations (Table 2). The connection of these units and the remaining functional groups was determined on the basis of the key HMBC correlations summarized in Fig. 2.

The acetylation of $\mathbf{1}$ gave tetraacetate $\mathbf{3}$, and the proton signals for 2-H, 6- $\mathrm{H}, 8-\mathrm{H}$ and $\mathrm{H}-12$ were downfield-shifted from $\delta_{\mathrm{H}} 3.74, \delta_{\mathrm{H}} 3.80, \delta_{\mathrm{H}} 3.87$ and $\delta_{\mathrm{H}} 4.19,4.32$ to $\delta_{\mathrm{H}}$ $4.92, \delta_{\mathrm{H}} 5.66, \delta_{\mathrm{H}} 5.18$ and $\delta_{\mathrm{H}} 4.74$, respectively. This observation, together with the molecular formula of $\mathbf{1}$, implied that the positions of the hydroxyl groups were at C2 , C-6, C-8 and C-7 ( $\left.\delta_{\mathrm{C}} 80.42\right)$, thus elucidating the planar structure of 1 .

The relative stereochemistry of $\mathbf{1}$ was deduced from NOESY experiments (Fig. 3). NOE correlations from $15-\mathrm{H}$ to $1 \beta-\mathrm{H}$ and $3 \beta-\mathrm{H}$ implied the $\mathrm{A}$ ring to exist in a chair conformation with the 5-methyl group, $1 \beta$ - $\mathrm{H}$ and $3 \beta$ - $\mathrm{H}$ in coaxial arrangements. NOEs correlations $(15-\mathrm{H} / 10-\mathrm{H}, 14-$ $\mathrm{H} / 3 \beta-\mathrm{H}$ and $4-\mathrm{H} / 2-\mathrm{H})$ suggested the 5-methyl group to be oriented cis to $10-\mathrm{H}$, and the 2-hydroxyl group and the 4methyl group to be arranged equatorially. NOEs from $6-\mathrm{H}$ to $4-\mathrm{H}$ and from $9 \alpha-\mathrm{H}$ to $4-\mathrm{H}$ and from $8-\mathrm{H}$ to $10-\mathrm{H}$ implied that the $\mathrm{B}$ ring exists in a twist-boat conformation, and that $6-\mathrm{H}$ is oriented $c i s$ to both the C-4-C-5 bond and the 8-hydroxyl group. In addition, NOEs correlations (6$\mathrm{H} / 13 \mathrm{~A}-\mathrm{H}$ and $9 \alpha-\mathrm{H} / 13 \mathrm{~A}-\mathrm{H})$ suggested that the C-7-C-11

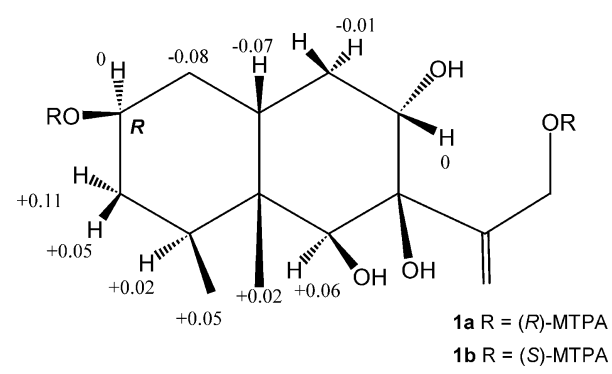

Fig. $4{ }^{1} \mathrm{H}$ chemical-shift differences $\left(\Delta \delta=\delta_{S}-\delta_{R}\right)$ between the (R)- and (S)-MTPA esters (1a and $\mathbf{1 b})$ of peribysin $\mathrm{J}(\mathbf{1})$.

bond is oriented cis to 6-H. Consequently, the relative stereostructure for $\mathbf{1}$ can be depicted as shown in Fig. 3.

The modified Mosher method [11] was applied to determine the absolute configuration of 1 . The ${ }^{1} \mathrm{H}$ chemical-shift differences between the $(R)$ - and $(S)$-MTPA esters (1a and 1b) of $\mathbf{1}$ are shown in Fig. 4. The result suggested that 1 has the $2 R$ configuration. Hence the absolute stereostructure of 1 was determined as $2 R, 4 S, 5 R$, $6 S, 7 R, 8 S, 10 R$.

2 was assigned the molecular formula $\mathrm{C}_{16} \mathrm{H}_{22} \mathrm{O}_{8}$ deduced from HREI-MS. Its IR spectrum exhibited bands at 3450, $1722,1717,1658$ and $1652 \mathrm{~cm}^{-1}$, characteristic of hydroxy and carbonyl groups, and a double bond. A close inspection of the ${ }^{1} \mathrm{H}$ - and ${ }^{13} \mathrm{C}-\mathrm{NMR}$ spectra of $\mathbf{2}$ (Table 3) by DEPT and HMQC experiments revealed the presence of three secondary methyls (C-17, C-18 and C-19), one $s p^{3}$ hybridized methylene (C-2), five oxygen-bearing $s p^{3}$ methines (C-3, C-8, C-9, C-14 and C-15), two 1,2-disubstituted double bonds (C-6, C-7, C-12 and C-13) and three ester carbonyl groups. The ${ }^{1} \mathrm{H}-{ }^{1} \mathrm{H}$ COSY analysis of $\mathbf{2}$ led to three carboxylic acid units as shown by bold faced lines in Fig. 5, which was supported by HMBC correlations (Table 3 ). The $E$-geometry of both the $\Delta^{6}$ - and $\Delta^{12}$-double bonds was deduced from the coupling constants $\left(J_{6,7}\right.$ $15.8 \mathrm{~Hz}$ and $J_{12,13} 15.2 \mathrm{~Hz}$ ) of the olefinic protons. The connection of these three units and remaining ester moiety was determined on the basis of the key HMBC correlations (7-H/C-5, 6-H/C-5, 3-H/C-5, 3-H/C1, 2-H/C-1, 14-H/C-1, 13-H/C-11, 12-H/C-11 and 9-H/C-11) (Table 3, Fig. 5), leading to the planar structure of 2 .

Since the stereostructure of $\mathbf{2}$ could not be deduced from NOESY experiments, $\mathbf{2}$ was degraded to the methyl esters of the constituent carboxylic acids. Acid-catalyzed methanolysis of $\mathbf{2}$ in $\mathrm{MeOH}$ gave only two products, methyl esters of 3-hydroxybutyric acid and 4,5-dihydroxyhex-2Eenoic acid, which were isolated as $p$-bromobenzoates (respectively $\mathbf{4}$ and $\mathbf{5}$ ) because of the volatility of methyl 3- 
Table 3 NMR spectral data of macrosphelide $\mathrm{M}(\mathbf{2})$ in $\mathrm{Me}_{2} \mathrm{CO}-d_{6}$

\begin{tabular}{|c|c|c|c|c|c|}
\hline Position & $\delta_{\mathrm{H}}{ }^{a}$ & $\mathrm{~J} / \mathrm{Hz}$ & ${ }^{1} \mathrm{H}-{ }^{1} \mathrm{H}$ COSY & $\delta_{\mathrm{C}}$ & $\operatorname{HMBC}(C)^{b}$ \\
\hline 1 & & & & 169.08 (s) & \\
\hline $2 \mathrm{~A}$ & $2.51 \mathrm{dd}$ & $15.2(2 B), 10.6(3)$ & $2 \mathrm{~B}, 3$ & $42.12(t)$ & $1,3,19$ \\
\hline B & $2.89 \mathrm{dd}$ & $15.2(2 A), 4.1(3)$ & $2 \mathrm{~A}, 3$ & & 1 \\
\hline 3 & $5.28 \mathrm{dqd}$ & $10.6(2 A), 6.0(19), 4.1(2 B)$ & $2 \mathrm{~A}, 2 \mathrm{~B}, 19$ & $68.99(d)$ & 1,5 \\
\hline 5 & & & & 166.22 (s) & \\
\hline 6 & $6.08 \mathrm{dd}$ & $15.8(7), 2.2(8)$ & 7 & $122.92(d)$ & 5,8 \\
\hline 7 & $7.04 \mathrm{dd}$ & $15.8(6), 4.5(8)$ & 6,8 & $147.26(d)$ & 5 \\
\hline 8 & $4.47 \mathrm{brs}$ & & $7,9,8-\mathrm{OH}$ & 75.11 (d) & $6,7,9,18$ \\
\hline 9 & $5.12 \mathrm{qd}$ & $6.2(18), 3.0(8)$ & 8,18 & $75.24(d)$ & 8,11 \\
\hline 11 & & & & 164.71 (s) & \\
\hline 12 & $5.89 \mathrm{dd}$ & $15.2(13), 1.1(14)$ & 13 & $126.16(d)$ & 11,14 \\
\hline 13 & $6.47 \mathrm{dd}$ & $15.2(12), 8.8(14)$ & 12,14 & 144.39 (d) & 11 \\
\hline 14 & $5.18 \mathrm{ddd}$ & $8.8(13), 5.5(15), 1.1(12)$ & 13,15 & 78.19 (d) & 1,12 \\
\hline 15 & 3.90 qdd & $6.0(17), 5.5(14), 4.9(15-\mathrm{OH})$ & $14,17,15-\mathrm{OH}$ & $68.49(d)$ & \\
\hline 17 & $1.14 \mathrm{~d}$ & $6.0(15)$ & 15 & $19.12(q)$ & 14,15 \\
\hline 18 & $1.39 \mathrm{~d}$ & $6.2(9)$ & 9 & $17.95(q)$ & 8,9 \\
\hline 19 & $1.36 \mathrm{~d}$ & $6.0(3)$ & 3 & $20.08(q)$ & 2,3 \\
\hline $8-\mathrm{OH}$ & $4.56 d$ & $4.9(8)$ & 8 & & 7,9 \\
\hline $15-\mathrm{OH}$ & $4.17 \mathrm{~d}$ & $4.9(15)$ & 15 & & 17 \\
\hline
\end{tabular}

${ }^{\mathrm{a}}$ and ${ }^{\mathrm{b}}$ as in Table 1.

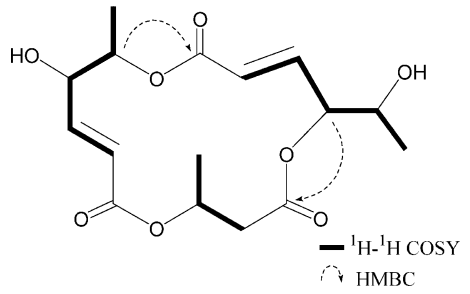

Fig. 5 Selected ${ }^{1} \mathrm{H}-{ }^{1} \mathrm{H}$ COSY and $\mathrm{HMBC}$ correlations in macrosphelide $\mathrm{M}(\mathbf{2})$.

hydroxybutyrate (Scheme 1). This fact demonstrated that the two dihydroxycarboxylic acid moieties of $\mathbf{2}$ have the same stereochemistry. These degradation products from 2 were identical with those derived from macrosphelide $\mathrm{E}$ by comparison of spectral data reported previously (Scheme 1) [4]. Hence, 4 and 5 were identified as methyl (3R)-3-( $p$ bromobenzoyloxy)butyrate and methyl $(4 R, 5 S)-4,5-\operatorname{di}(p-$ bromobenzoyloxy)hex-2E-enoate, respectively. The above summarized evidence led to the absolute stereostructure 2 for macrosphelide $\mathrm{M}$.

$\mathbf{1}$ and $\mathbf{2}$ were evaluated in the adhesion assay system using HL-60 cells and HUVEC, according to a modification of the method reported by Miki and coworkers [12]. As shown in Table 4, these compounds inhibited the adhesion of HL-60 cell to HUVEC more potently than herbimycin A $[9,10]$.

\section{Experimental}

\section{General}

UV spectra were recorded on a Shimadzu spectrophotometer and IR spectra on a Perkin Elmer FT-IR spectrometer $1720 \mathrm{X}$. NMR spectra were recorded at $27^{\circ} \mathrm{C}$ on Varian UNITY INOVA-500 and MERCURY spectrometers with tetramethylsilane (TMS) as an internal reference. EI-MS was determined using a Hitachi M$4000 \mathrm{H}$ mass spectrometer. Optical rotations were recorded on a JASCO J-820 polarimeter. Liquid chromatography over silica gel (mesh 230 400) was performed at medium pressure. HPLC was run on a Waters ALC-200 instrument equipped with a differential refractometer ( $R$ 401) and Shim-pack PREP-ODS ( $25 \mathrm{~cm} \times 20 \mathrm{~mm}$ i.d.). Analytical TLC was performed on precoated Merck aluminium sheets (DC-Alufolien Kieselgel 60 F254, $0.2 \mathrm{~mm}$ ) with the solvent system $\mathrm{CH}_{2} \mathrm{Cl}_{2}-\mathrm{MeOH}(9: 1)$, and compounds were viewed under UV lamp and sprayed with $10 \% \mathrm{H}_{2} \mathrm{SO}_{4}$ followed by heating.

\section{Culturing and Isolation of Metabolites}

A strain of $P$. byssoides OUPS-N133, isolated from the sea 

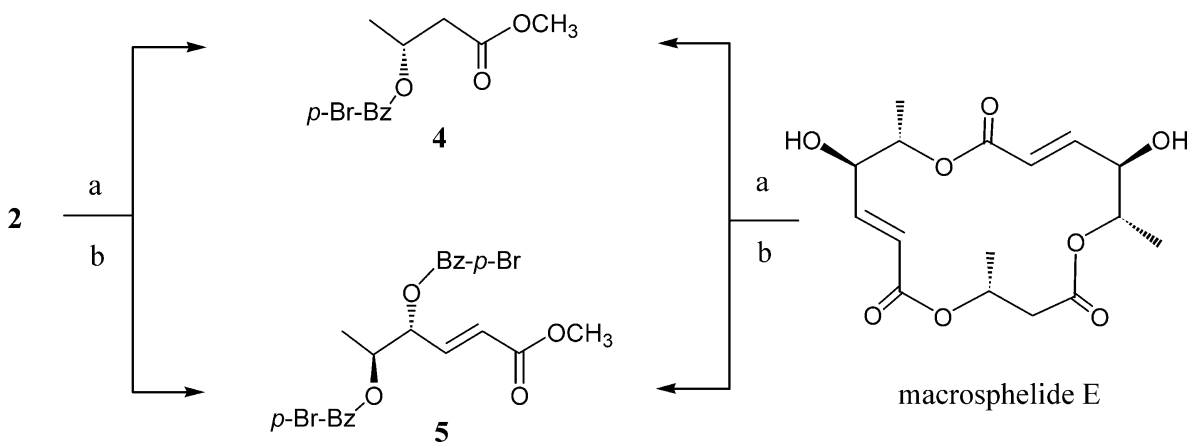

Scheme 1 Reaction conditions: (a) $\mathrm{MeOH}, \mathrm{H}_{2} \mathrm{SO}_{4}$; (b) $p$ - $\mathrm{Br}-\mathrm{BzCl}$, pyridine.

Table 4 Inhibitory activity of cell adhesion of metabolites

\begin{tabular}{cc}
\hline Compound & $\mathrm{IC}_{50}(\mu \mathrm{M})$ \\
\hline Peribysin J (1) & 11.8 \\
Macrosphelide M (2) & 33.2 \\
Herbimycin A (control) & 38.0 \\
\hline
\end{tabular}

hare A. kurodai, was cultured at $27^{\circ} \mathrm{C}$ for four weeks in a liquid medium (90 liters) containing malt extract $1.0 \%$, glucose $1.0 \%$ and peptone $0.05 \%$ in artificial seawater adjusted to $\mathrm{pH}$ 7.5. As reported previously [4], the EtOAc extract $(5.7 \mathrm{~g})$ of the culture filtrate was successively chromatographed on Sephadex LH-20 $\left(\mathrm{CH}_{2} \mathrm{Cl}_{2}-\mathrm{MeOH}\right.$, $1: 1)$ and silica gel $\left(\mathrm{CH}_{2} \mathrm{Cl}_{2}-\mathrm{MeOH}\right)$. The $\mathrm{MeOH}-\mathrm{CH}_{2} \mathrm{Cl}_{2}$ $(10: 90)$ eluate $(254.6 \mathrm{mg})$ from silica gel column chromatography was purified by HPLC using $\mathrm{MeOH}-\mathrm{H}_{2} \mathrm{O}$ $(40: 60)$ as the eluent to afford $1(8.8 \mathrm{mg}, 0.15 \%)$, and the $\mathrm{MeOH}-\mathrm{CH}_{2} \mathrm{Cl}_{2}(5: 95)$ eluate $(315.7 \mathrm{mg})$ from silica gel column chromatography was purified by HPLC using $\mathrm{MeOH}-\mathrm{H}_{2} \mathrm{O}(50: 50)$ as the eluent to afford $2(11.1 \mathrm{mg}$, $0.19 \%)$.

\section{Acetylation of 1}

To a solution of $\mathbf{1}(2.8 \mathrm{mg})$ in pyridine $(1.0 \mathrm{ml})$ was added $\mathrm{Ac}_{2} \mathrm{O}(1.0 \mathrm{ml})$, and the reaction mixture was left at room temperature overnight. The mixture was evaporated under reduced pressure and residue was purified by HPLC using $\mathrm{MeOH}-\mathrm{H}_{2} \mathrm{O}(70: 30)$ as the eluent to afford tetraacetate 3 $(1.8 \mathrm{mg})$ as a pale yellow oil.

Tetraacetate 3: EI-MS $m / z 454\left(\mathrm{M}^{+}, 2.5 \%\right)$; HREI-MS $\mathrm{m} / \mathrm{z}$ for $\mathrm{C}_{23} \mathrm{H}_{34} \mathrm{O}_{9}\left(\mathrm{M}^{+}\right)$, Calcd: 454.2193; Found: 454.2196; ${ }^{1} \mathrm{H}-\mathrm{NMR} \delta \mathrm{ppm}\left(\mathrm{CDCl}_{3}\right): 0.87(3 \mathrm{H}, \mathrm{d}, J=6.6 \mathrm{~Hz}, 14-\mathrm{H})$, $0.97(3 \mathrm{H}, \mathrm{s}, 15-\mathrm{H}), 1.36(1 \mathrm{H}, \mathrm{q}, J=11.8 \mathrm{~Hz}, 3 \beta-\mathrm{H}), 1.64$ $(2 \mathrm{H}, \mathrm{m}, 1-\mathrm{H}), 1.81(1 \mathrm{H}, \mathrm{dt}, J=11.8,4.8 \mathrm{~Hz}, 3 \alpha-\mathrm{H}), 1.82$ $(1 \mathrm{H}, \mathrm{m}, 10-\mathrm{H}), 2.01\left(3 \mathrm{H}, \mathrm{s}, \mathrm{COOCH}_{3}\right), 2.06(3 \mathrm{H}, \mathrm{s}$, $\left.\mathrm{COOCH}_{3}\right), 2.06(2 \mathrm{H}, \mathrm{m}, 9-\mathrm{H}), 2.10(1 \mathrm{H}, \mathrm{dqd}, J=11.8,6.6$,
$4.8 \mathrm{~Hz}, 4-\mathrm{H}), 2.11\left(6 \mathrm{H}, \mathrm{s}, \mathrm{COOCH}_{3}\right), 2.11(1 \mathrm{H}, \mathrm{br} \mathrm{s}, 2-\mathrm{OH})$, $4.74(2 \mathrm{H}, \mathrm{s}, 12-\mathrm{H}), 4.92(1 \mathrm{H}, \mathrm{tt}, J=11.8,4.8 \mathrm{~Hz}, 2-\mathrm{H}), 5.18$ $(1 \mathrm{H}, \mathrm{dd}, J=10.3,5.1 \mathrm{~Hz}, 8-\mathrm{H}), 5.43(1 \mathrm{H}, \mathrm{s}, 13 \mathrm{~A}-\mathrm{H}), 5.46$ $(1 \mathrm{H}, \mathrm{s}, 13 \mathrm{~B}-\mathrm{H}), 5.66(1 \mathrm{H}, \mathrm{br} \mathrm{s}, 6-\mathrm{H})$.

\section{Formation of the $(R)$ - and $(S)$-MTPA Esters 1a and 1b from 1}

(R)-MTPA (2.0 mg), dicyclohexylcarbodiimide (DCC) $(2.0 \mathrm{mg})$ and 4-(dimethylamino)-pyridine (DMAP) $(1.0 \mathrm{mg})$ were added to a $\mathrm{CH}_{2} \mathrm{Cl}_{2}$ solution $(0.2 \mathrm{ml})$ of $\mathbf{1}(1.2 \mathrm{mg})$, and the reaction mixture was left at room temperature for 3 hours. The solvent was evaporated off under reduced pressure, and the residue was purified by HPLC using $\mathrm{MeOH}-\mathrm{H}_{2} \mathrm{O}(65: 35)$ as the eluent to afford $(R)$-MTPA ester 1a $(0.9 \mathrm{mg})$ as an amorphous powder. The same reaction with $1(1.4 \mathrm{mg})$ using $(S)$-MTPA $(2.1 \mathrm{mg})$ gave ester $\mathbf{1 b}(1.0 \mathrm{mg})$.

Ester 1a: EI-MS $m / z 700\left(\mathrm{M}^{+}, 1.2 \%\right)$; HREI-MS $m / z$ for $\mathrm{C}_{35} \mathrm{H}_{40} \mathrm{~F}_{6} \mathrm{O}_{9} \quad\left(\mathrm{M}^{+}+\mathrm{H}_{2} \mathrm{O}\right)$, Calcd: 718.2565; Found: $718.2572 ;{ }^{1} \mathrm{H}-\mathrm{NMR} \delta \mathrm{ppm}\left(\mathrm{CDCl}_{3}\right): 0.77(3 \mathrm{H}, \mathrm{d}$, $J=6.9 \mathrm{~Hz}, 14-\mathrm{H}), 0.99(3 \mathrm{H}, \mathrm{s}, 15-\mathrm{H}), 1.35(1 \mathrm{H}, \mathrm{q}$, $J=12.2 \mathrm{~Hz}, 3 \beta-\mathrm{H}), 1.71(1 \mathrm{H}, \mathrm{m}, 3 \alpha-\mathrm{H}), 1.74(2 \mathrm{H}, \mathrm{m}, 1-\mathrm{H})$, $1.90(1 \mathrm{H}, \mathrm{m}, 9 \beta-\mathrm{H}), 1.98(1 \mathrm{H}, \mathrm{m}, 9 \alpha-\mathrm{H}), 2.00(1 \mathrm{H}, \mathrm{m}, 4-$ $\mathrm{H}), 2.14(1 \mathrm{H}, \mathrm{m}, 10-\mathrm{H}), 3.55\left(6 \mathrm{H}, \mathrm{s}, \mathrm{OCH}_{3}\right), 3.80(1 \mathrm{H}, \mathrm{s}, 6-$ $\mathrm{H}), 4.00(1 \mathrm{H}, \mathrm{dd}, J=10.1,5.6 \mathrm{~Hz}, 8-\mathrm{H}), 4.90(1 \mathrm{H}, \mathrm{d}$, $J=13.8 \mathrm{~Hz}, 12 \mathrm{~A}-\mathrm{H}), 5.05(1 \mathrm{H}, \mathrm{d}, J=13.8 \mathrm{~Hz}, 12 \mathrm{~B}-\mathrm{H}), 5.18$ $(1 \mathrm{H}, \mathrm{m}, 2-\mathrm{H}), 5.47(1 \mathrm{H}, \mathrm{s}, 13 \mathrm{~A}-\mathrm{H}), 5.77(1 \mathrm{H}, \mathrm{s}, 13 \mathrm{~B}-\mathrm{H})$, $7.41(6 \mathrm{H}, \mathrm{m}, \mathrm{Ar} . \mathrm{H})$ and $7.52(4 \mathrm{H}, \mathrm{m}, \mathrm{Ar} . \mathrm{H})$.

Ester 1b: EI-MS $m / z 700\left(\mathrm{M}^{+}, 0.9 \%\right)$; HREI-MS $m / z$ for $\mathrm{C}_{35} \mathrm{H}_{40} \mathrm{~F}_{6} \mathrm{O}_{8}\left(\mathrm{M}^{+}+\mathrm{H}_{2} \mathrm{O}\right)$, Calcd: 718.2565; Found: 718.2570; ${ }^{1} \mathrm{H}-\mathrm{NMR} \delta \mathrm{ppm}\left(\mathrm{CDCl}_{3}\right): 0.82(3 \mathrm{H}, \mathrm{d}, J=6.9 \mathrm{~Hz}$, $14-\mathrm{H}), 1.01(3 \mathrm{H}, \mathrm{s}, 15-\mathrm{H}), 1.46(1 \mathrm{H}, \mathrm{q}, J=12.2 \mathrm{~Hz}, 3 \beta-\mathrm{H})$, $1.66(2 \mathrm{H}, \mathrm{m}, 1-\mathrm{H}), 1.76(1 \mathrm{H}, \mathrm{m}, 3 \alpha-\mathrm{H}), 1.89(1 \mathrm{H}, \mathrm{m}, 9 \beta-$ $\mathrm{H}), 1.90(1 \mathrm{H}, \mathrm{m}, 9 \alpha-\mathrm{H}), 2.02(1 \mathrm{H}, \mathrm{m}, 4-\mathrm{H}), 2.07(1 \mathrm{H}, \mathrm{m}$, $10-\mathrm{H}), 3.54\left(3 \mathrm{H}, \mathrm{s}, \mathrm{OCH}_{3}\right), 3.56\left(3 \mathrm{H}, \mathrm{s}, \mathrm{OCH}_{3}\right), 3.86(1 \mathrm{H}$, s, 6-H), $4.00(1 \mathrm{H}, \mathrm{dd}, J=10.1,5.6 \mathrm{~Hz}, 8-\mathrm{H}), 4.88(1 \mathrm{H}, \mathrm{d}$, $J=13.8 \mathrm{~Hz}, 12 \mathrm{~A}-\mathrm{H}), 5.03(1 \mathrm{H}, \mathrm{d}, J=13.8 \mathrm{~Hz}, 12 \mathrm{~B}-\mathrm{H}), 5.18$ $(1 \mathrm{H}, \mathrm{m}, 2-\mathrm{H}), 5.40(1 \mathrm{H}, \mathrm{s}, 13 \mathrm{~A}-\mathrm{H}), 5.74(1 \mathrm{H}, \mathrm{s}, 13 \mathrm{~B}-\mathrm{H})$, 
$7.41(6 \mathrm{H}, \mathrm{m}, \mathrm{Ar} . \mathrm{H})$ and $7.52(4 \mathrm{H}, \mathrm{m}, \mathrm{Ar} . \mathrm{H})$.

\section{$p$-Bromobenzoate 4 and 5 of Degradation Products from 2}

To a solution of $2(2.6 \mathrm{mg})$ in $\mathrm{MeOH}(0.1 \mathrm{ml})$ was added conc. $\mathrm{H}_{2} \mathrm{SO}_{4}(0.02 \mathrm{ml})$, and the reaction mixture was left at room temperature overnight. The mixture was diluted with water and extracted with diethyl ether, and the extract was evaporated under reduced pressure to give a mixture of crude methyl carboxylate. To a solution of the mixture in pyridine $(0.2 \mathrm{ml})$ was added $p$-bromobenzoyl chloride $(3.2 \mathrm{mg})$, and the reaction mixture was left at room temperature overnight. The mixture was concentrated to dryness under reduced pressure, and the residue was purified by HPLC using $\mathrm{MeOH}-\mathrm{H}_{2} \mathrm{O}(90: 10)$ as the eluent to afford $p$-bromobenzoates $4(0.5 \mathrm{mg})$ and $\mathbf{5}(1.1 \mathrm{mg})$ as a pale yellow oil. The spectral data, including CD spectra, of 4 and 5 were identical with those of the degradation products from macrosphelide E reported previously [4].

\section{Cell Adhesion Assay}

This assay was carried out according to a modification of the Miki's method using 3-(4,5-di-methyl-2-thiazolyl)-2,5diphenyl-2 $H$-tetrazolium bromide (MTT)-labeled cells [12]. HUVEC (DIA-IATRON Co., Ltd.) were cultured until confluent in a 96-well plate in medium 199 (Gibco) containing $10 \%$ fetal calf serum (FCS, Gibco) and washed with phosphate buffered saline (PBS, DIA-IATRON Co., Ltd.) containing $20 \%$ FCS. The HUVEC were stimulated with a solution of lipopolysaccharides (LPS, Sigma) in RPMI 1640 medium (Gibco) containing 10\% FCS for 4 hours in the presence of various concentrations of macrosphelides, and then MTT-labeled HL-60 cells were added and incuvated for 40 minutes at $37^{\circ} \mathrm{C}$ in $5.0 \% \mathrm{CO}_{2}$. Unbound cells were gently washed out with PBS containing $10 \% \mathrm{FCS}$, and DMSO was added to lyse the adherent HL-60 cells. Absorbance at $540 \mathrm{~nm}$ was measured using a microplate reader (Model 450, BIO-RAD).

Acknowledgements We thank Dr. K. Kawai (Fuso Pharmaceutical Industries, Ltd.) for his helpful advice on cell adhesion assay.

\section{References}

1. Amagata $T$, Doi M, Ohta $T$, Minoura $K$, Numata A. Absolute stereostructures of novel cytotoxic metabolites, gymnastatins $\mathrm{A} \sim \mathrm{E}$, from a Gymnascella species separated from a Halichodria sponge. J Chem Soc Perkin Trans 1 3585-3599 (1998), and references cited therein

2. Amagata T, Doi M, Tohgo M, Minoura K, Numata A. Dankasterone, a new class of cytotoxic steroid produced by a Gymnascella species from a marine sponge. Chem Commun 1321-1322 (1999)

3. Iwamoto C, Yamada T, Ito Y, Minoura K, Numata A. Cytotoxic cytochalasans from a Penicillium species separated from a marine alga. Tetrahedron 57: 2997-3004 (2001)

4. Yamada T, Iritani M, Doi M, Minoura K, Ito T, Numata A. Absolute stereostructures of cell adhesion inhibitors, macrosphelides $\mathrm{C}, \mathrm{E} \sim \mathrm{G}$ and $\mathrm{I}$, produced by a Periconia species separated from an Aplysia sea hare. J Chem Soc Perkin Trans 1 3046-3053 (2001)

5. Yamada T, Iritani M, Minoura K, Numata A. Absolute stereostructures of cell adhesion inhibitors, macrosphelide $\mathrm{H}$ and L, from Periconia byssoides OUPS-N133. J Antibiot 55: 147-154 (2002)

6. Yamada T, Iritani M, Minoura K, Kawai K, Numata A. Peribysin $\mathrm{A} \sim \mathrm{D}$, potent cell-adhesion inhibitors from a sea hare-derived culture of Periconia species. J Org Biomol Chem 2131-2135 (2004)

7. Yamada T, Doi M, Miura A, Harada W, Hiramura M, Minoura K, Tanaka R, Numata A. Absolute stereostructures of cell adhesion inhibitors, peribysin A, E, F and G, produced by a sea hare-derived Periconia sp. J Antibiotics 58: 185-191 (2005)

8. Yamada T, Minoura K, Tanaka R, Numata A. Cell-adhesion inhibitors produced by a sea hare-derived Periconia sp. II Absolute stereostructures of peribysin $\mathrm{H}$ and I. J Antibiot 59: 345-350 (2006)

9. Weber C, Negrescu E, Erl W, Piersch A, Frankenberger M, Ziegler-Heitbrock HWL, Siess W, Weber PC. Inhibitors of protein tyrosine kinase suppress TNF-stimulated induction of endothelial cell adhesion molecules. J Immunol 155: 445-451 (1995)

10. May MJ, Wheeler-Jones CPD, Pearson JD. Effects of protein tyrosine kinase inhibitors on cytokine-induced adhesion molecule expression by human umbilical vein endothelial cells. Br J Pharmacol 118: 1761-1771 (1996)

11. Ohtani I, Kusumi T, Kashman Y, Kakizawa H. High-field FT NMR application of Mosher's method. The absolute configurations of marine terpenoids. J Am Chem Soc 113: 4092-4096 (1991)

12. Miki I, Ishihara N, Otoshi M, Kase H. Simple colorimetric cell-cell adhesion assay using MTT-stained leukemia cells. J Immunol Methods 164: 255-261 (1993) 